\title{
Türkiye'de Ulusal Mevzuata Göre Velilerin Okul Yönetimine Katılımı
}

\begin{abstract}
Ali İhsan ÇUHADAR*
Öz: Bu çalışmanın amacı Türkiye'de velilerin okul yönetimine katılmalarını düzenleyen ulusal mevzuatın ve velilerin okul yönetimine katılımı ile ilgili daha önceden yapılan araştırmalarda bu mevzuata yer verilme durumunun incelenmesidir. Nitel bir araştırma olarak tasarlanan bu araştırmada doküman incelemesi yöntemi kullanılmıştır. Araştırma kapsamında Haziran 2019 tarihi itibarıyla yürürlükte olan ulusal mevzuat ve belirlenen ölçütleri karşılayan 4 Tez ve 9 makale içerik analizi ile incelenmiştir. Araştırma sonucunda ulusal mevzuatta 39 maddenin velilerin yönetime katılımını düzenlediği görülmüştür. Bu maddelerin, Kartal'ın (2008) yönetime katılım sınıflandırmasına uygun olarak 14'ünün kurul üyeliği, 13’ünün komisyon üyeliği, 5'inin yönetime görüş ve öneri bildirme ve 7'sinin yönetime yardımcı olmak şeklinde yer aldığı görülmüştür. Ailelerin eğitime katılımı ile ilgili daha önce yapılan araştırmaların bir kısmında mülga yönetmeliğe atıf yapıldığı, bir kısmında sadece okul aile birliği yönetmeliğinin incelendiği, bir kısmında ilgili diğer mevzuatların taranmadığı, dolayısıyla mevzuatla ilgili taramaların sistematik olmadığı ve araştırmaların bu yönünün eksik çalışıldığı tespit edilmiştir.

Anahtar kelimeler: Veli, Okul yönetimine katılım, Ulusal mevzuat, Velinin eğitime katılımı

\section{Parents' İnvolvement in School Management According to National Legislation in Türkiye}

\begin{abstract}
The aim of this study is that national legislation regulating the participation of parents in school management and parents in Turkey than in earlier surveys related to their participation in school management is to examine this legislation in place given the circumstances. The study was designed as a qualitative research method was used in document examination. Within the scope of the research, as of June 2019, 4 theses and 9 articles that meet the national legislation and determined criteria were analyzed with content analysis. As a result of the study, it has been seen that 39 articles regulates the parental involvement in management. In these clauses, accordance with the Kartal's (2008) classification of the participation in
\end{abstract}

\footnotetext{
* Doktora Öğrencisi, Ankara Üniversitesi Eğitim Bilimleri Enstitüsü, Eğitim Yönetimi ve Teftişi Programı, Orcid No: https://orcid.org/0000-0001-7233-6329, iletişim:cuhadarihsanali@gmail.com
} 
management, it has been seen that 14 of them take place in committee membership, 13 of them in commission membership, 5 of them in reporting opinions and suggestions to the management, 7 of them in helping the management. It has been understood that in some parts of the studies that has been made before about the parental involvement in management, repealed regulations have been used, in other parts only the parent-teacher association is examined, in other parts other relevant regulations have not been surveyed, thereby the surveys about regulations are not systematic and this part of the studies are studied imperfectly.

Keywords: Parents, involvement in school management, national legislation, parents' involvement in education

\section{Giriş}

Çevresini etkileyen ve çevresinden etkilenen, açık sistemler olarak nitelendirilebilecek okullar yönetim bilimindeki gelişmelere paralel olarak yeniden tasarlanmaktadır. Son yıllarda demokratik okul, okul merkezli yönetim, toplam kalite yönetimi, stratejik yönetim gibi modern yönetim teorilerinde katılımcılık, demokrasi, şeffaflık, yönetişim, hesap verebilirlik gibi okul toplumunun tüm üyelerinin yönetimde söz ve bilgi sahibi olduğu kavramların ön plana çıkarıldığı görülmektedir. Okul müdürünün tüm yetkileri elinde bulundurduğu ve tüm kararları tek başına aldığı otokratik yönetim modellerinin 21. yüzyıl için halen geçerli olduğunu söylemek pek de mümkün değildir.

Yönetici, öğretmen, öğrenci ve aile eğitim sisteminin en önemli temel bileşenleridir. Başarılı bir eğitim ve öğrenci başarısı için bu temel bileşenler uyum ve işbirliği içinde çalışmalıdır. Bileşenlerin uyum ve işbirliği içinde çalışması ise veli ve öğrencilerin yönetime katılmasını desteklemek ile sağlanabilir (Tican Başaran ve Koç, 2001). Velilerin eğitim öğretime katılımı Ortaöğretim Kurumları Yönetmeliğinin 34'üncü maddesince düzenlenmiştir. Bu maddeye göre; veli, öğrencinin annesi, babası veya yasal yükümlülüğünü üstlenen kişidir ve doğrudan öğrencinin eğitim ve öğretiminde söz sahibidir. Yönetmelikte sayılan bazı özel durumlarda okul yöneticilerinden biri de veli olabilmektedir (MEB, 2013a).

Yönetime katılım, işgörenlerin örgütsel kararlarda ve sorunların çözümünde söz sahibi olmasıdır (Başaran, 1992). Bir örgütte işgörenlerin temsilcileri aracılığıyla, o örgütte alınan ve kendilerini etkileyen her tür kararda söz ve oy sahibi olması yönetime katılma olarak adlandırılabilir (Dicle, 1980). Yapısal olarak yönetime katılma bireylerin karar verme hiyerarşisi içerisinde bir yere sahip olmasıdır (Denhart, 1972; Akt., Eroğlu, 2006). Bu tanımlara 
göre bir örgütte alınacak kararlardan etkilenecek olası kişilerin, görüşlerine başvurmak, onlarla tartışmak ya da onların temsili bir sistemle kurullarda yer almaları yönetime katılma olarak tanımlanabilir (Vural, 1989).

Yönetime katılmada, katılımın sağlanması ve sonuçların izlenmesi çok önemlidir. Yönetimde alınan ortak karar sayısı arttıkça, yönetimin sağlayacağı faydalar da artacaktır. Yönetici zamanla karar verme yetkisini paylaşacak, yönetilenler de kararlarda söz sahibi oldukça daha sorumlu davranacaklardır (Eroğlu, 2006).

Eğitime ailenin katılımı okul ile anne-babalar arasında çok boyutluluğa dayalı her çeşit iletişim ve etkileşimdir (Epstein, 1995). Epstein (2010) aile katılımını Tip 1-Ebeveynlik, Tip 2-İletişim, Tip 3-Gönüllülük, Tip 4-Evde öğrenme, Tip 5-Karar verme, Tip 6- Toplumla işbirliği olmak üzere altı kategoriye ayırarak incelemiştir. O’na göre karar verme kategorisi öğretmenlerin, öğrencilerin ve velilerin okul yönetimine katılımını ve karar mekanizmalarında yer almasını ifade eden bir katılım türüdür.

Yönetime katılma çoğu zaman demokratik yönetimle eş anlamlı olarak da kullanılmaktadır (Karayazı, 2007). Demokratik okullarda veliler okulla gerektiği kadar ilgilidir ve alınan kararlarda söz sahibidir (Şişman, Güleş, ve Dönmez, 2010). Demokratik okullarda öğrenciler, öğretmenler, aileler ve okul toplumunun diğer üyelerinin temsil edildiği seçim ve karar verme süreçlerine sahip yapılar vardır (Council of Europa, 2005). Demokratik okullarda kararlardan etkilenen tüm kesimlerin kararların alınmasında da söz sahibi olması gerekir (Bayrakçı ve Dizbay, 2013). Demokratik okulların yönetiminde geniş bir katılımın olması esastır. Kararların alındığı kurullar ve komisyonlarda öğretmenler ve yöneticilerin yanında öğrenciler, veliler ve okulun diğer çalışanlarının da olması demokrasi kültürünün oluşmasını destekler (Şişman ve diğ., 2010).

Karar verme yetkisinin merkezden okullara doğru kaydırılmasının 1980'lerden sonraki en önemli eğitim stratejisi olduğu söylenebilir. Eğitimle ilgili tüm kararların okulda alındığı okul yönetim biçimine "okula dayalı yönetim” denilmektedir. Okula dayalı yönetim eğitimin yerinden yönetim şeklidir. Okula dayalı yönetim şeklinde, eğitim öğretimi geliştirmek asıl amaçtır. Bu amacı gerçekleştirmek için, okul yönetiminin yetki ve sorumlulukları arttırılır, özerklik ve katılımlı karar almak esastır. Okullar temel karar alma birimi olarak kabul edilir. Okula dayalı yönetimde öğretmen, yönetici, veli ve öğrencinin katılımıyla kararların ortak alınması kararın niteliğini de artırır. Okula dayalı yönetim anlayışı, velilerin okul yönetimine 
dâhil edilmesine, toplumla bağlar oluşturulmasına katkılar sağlayacak ve "bizim okulumuz" anlayışını oluşturacaktır (Güçlü, 2000). Ailelerin okul yönetimine katılması velilerin öğrencilerin öğrenmeleri ile ilgili sorumluklar yüklenmesini sağlayacağı gibi eğitim kurumunun değişim ve gelişimine de katkı sunacaktır (Arslanargun, 2007). Okula dayalı /okul merkezli yönetimin üç temel özelliği; 1 - Mali işler, insan kaynakları ve öğretim programları gibi süreçlerde merkezi karar alma yetkisi okullara aktarılır, okul müdürü kadar öğretmen ve velilerde bu konularda yetkilidir. 2- Karar almada formal yetki okul müdürü, veliler ve okul toplumunun diğer üyeleri arasında paylaştırılır. 3- Okul toplumu üyeleri yürürlükteki ulusal mevzuata uygun olmak koşuluyla, okula özgü işleyişle ilgili kuralları belirlemeye yetkilidir (Malen, Ogawa ve Kranz 1989; Akt., Aytaç, 1999).

Ailelerin eğitime katılımına yönelik uygulamalar tüm dünya ülkelerinde önemsenmektedir (Özeke ve Kocabaş, 2006). Ailelerin eğitime katılımları ile öğrencilerin alacağı eğitimin kalitesi arasında doğrudan bir ilişki bulunmaktadır. Ailelerin eğitime katılımları eğitimin çıktıları açısından olumlu sonuçlar vermektedir (Zellman ve Waterman, 1998). Özellikle gelişmiş ülkelerde okul aile işbirliğinin daha etkin olması okuldaki karar mekanizmalarına ailelerin katılımı ile mümkün olmaktadır (Arslanargun, 2007). Öğrencilerin okulu önemseme tarzları aslında ailelerinin okulu önemseme tarzlarının yansımasıdır (Epstein, 2010). Okul ve aile arasındaki işbirliğinin temel amacı öğrenci ve okul başarısını yükseltmektir (Gümüşeli, 2004). Ailelerin eğitime katılımı ile öğrenci başarısı arasında olumlu bir ilişki vardır (Kotaman, 2008). Okul ile aile arasındaki işbirliği öğrencinin başarısını arttırdığı gibi, okuldaki disiplinsiz öğrenci davranışlarını da azalttığı araştırma sonuçlarında elde edilmiştir (Çalışkan ve Ayık, 2015; Kahramanoğlu ve Şahin, 2014).

Çocukların eğitiminde okulun tek başına yeterli olması olanaksızdır. Bu nedenle ailenin desteğine ihtiyaç vardır (Yıldırım ve Dönmez, 2008). Demokratik ve katılımcı okul yönetimleri, okuldaki öğrencilerin, öğretmenlerin ve öğrenci velilerinin karar alma süreçlerine katılması ile gerçekleşir (Şişman ve diğ., 2010). Okul yöneticileri okullarda iletişim ve işbirliğini güçlendirmek için velileri gönüllü görevler almaya teşvik etmeli, karar alma süreçlerine katmalı ve onlardan okula fayda sağlayacak şekilde yararlanma yollarını oluşturmalıdır (Şişman, 2010). Eğitim-öğretimde başarıyı yakalamak ve devam ettirmek isteyen okul yönetimlerinin, öğretmenin yanında anne-babaları da katılımcı hale getirebilmek için iletişime önem vermeleri gerekmektedir (Çalışkan ve Ayık, 2015). 
Velilerin katılımı, okulda eğitim süreçlerinin vazgeçilemeyecek bir parçası olarak görülmelidir. Velilerin yönetime katılmasının temelinde okulun sorunlarına çözüm üretmek ana amaç olmalıdır. Velilerin eğitime katılımı ile öğrencilerin eğitim kaliteleri yükselmekte ve başarıları artmaktadır. Türkiye'de yapılan araştırma sonuçlarına göre veli katılımı henüz istenilen düzeyde değildir (Argon ve Kıyıc1, 2012). Diğer taraftan yapılan araştırma sonuçlarına bakıldığında çocuğun yaşı ilerledikçe velinin eğitime katılımının azaldığı görülmektedir (Çınkır ve Nayır, 2007). Erol ve Turhan (2018) tarafından yapılan araştırmada öğrencinin yaşı ilerledikçe veli katılımının azaldığı, veli katılımı arttıkça öğrencinin okula bağlılık düzeyinin de arttığı, ayrıca öğrencilerin algılarına göre, veli eğitim seviyesi yükseldikçe aile katılımının da yükseldiği tespit edilmiştir.

Aile katılımının öğrenci başarısı üzerindeki olumlu katkısının farkına varan ülkeler, eğitime aile katılımını artırmak için düzenlemeler yapmaktadır. Amerika Eğitim Bakanlığı (U.S. Department of Education) kapsamlı eğitim reformunun 11 bileşeninden birisini de öğrencileri daha başarılı kılmak için ailelerin eğitime katılımını artırmak olarak belirlemiştir (Silver, 2004). Aile okulda yapılan sosyal, kültürel faaliyetlere katılarak çocuğun öğrenmesini desteklemenin yanında, okulun karar mekanizmalarında da yer alarak çocuğun ve okulun başarısının artmasına katkı sağlayabilir.

Velinin okulda yapılan faaliyetlerde yer alması öğrenciye moral destek verebileceği gibi, öğrencinin önemsendiği hissini de çocukta uyandırabilir (Gümüşeli, 2004). Okul ile düzenli ve sistemli görüş alış verişinde bulunan ve iletişimi iyi olan ailelerin çocuklarının diğer öğrencilere göre çok daha başarılı oldukları görülmüştür (Çelenk, 2003). Karar alma sürecine karardan etkilenecek kişilerin de katılmasıyla, katılımcılar alınan kararların sorumluluğunu da üstleneceklerinden daha nitelikli kararların alınması temin edilir ve kararların uygulanması kolaylaşır (Güçlü, 2000).

Ailelerin eğitime katılımının veliler tarafından dozunun iyi ayarlanması gerekir. Aşırı katılım öğrencilerin bulunduğu sınıf seviyelerine göre olumsuz etkiler de oluşturabilir. Aşırı katılım ilköğretimde öğrencilerin bağımsızlık gelişimini engelleyebileceği gibi, ortaöğretimde çocuğun akranları arasında onu zor durumda bırakabilir. Okul yönetimi ve öğretmenler aşırı katılımı, okulun işleyişine müdahale olarak ta algılayabileceğinden veli okul iletişimi zarar görebilir (Babaoğlan, Çelik ve Nalbant, 2018). Bu nedenle veli katılımında öğrencinin yaşı, bulunduğu sınıf seviyesi ve okul yönetiminin katılım ile ilgili tutumları göz önünde bulundurulmalıdır (Gümüşeli, 2004). 
Velilerin çoğunluğu okul aile işbirliğgine ilgi göstermemektedir (Akbaşlı ve Kavak, 2008; Aşlamacı ve Eker, 2017; Balkar, 2009). Türkiye gibi eğitim sisteminin merkeziyetçi olduğu ülkelerde bu yapılanma, velilerin çocukların eğitimlerine aktif olarak katılmaları yönündeki en büyük engellerden biridir (Kartal, 2008; Şimşek ve Tanaydın, 2002). Müdürlerin ve öğretmenlerin çoğunluğu velilerin karar süreçlerine katılmalarını kısıtlarlar. Öğretmenlerin aile katılımı çalışmaları kapsamında yönetim ve karar verme süreçlerine aileleri katmadıkları görülmektedir (Ünüvar, 2010). Okul yöneticilerinin bir k1smı yetkilerini veliler ve okul toplumu üyelerine dağıtmaktan kaçınırlarken bir kısmı yetkilerini okul politikası ile ilgili sorunların çözümünde veliler ve okul toplumu üyeleriyle paylaşırlar (Güçlü, 2000). Çınkır ve Nayır (2007) tarafından yapılan araştırmada görüşlerine başvurulan veliler okul yönetimlerinin velilerin katılımını sağlamak için uğraşmadıklarını belirtmişlerdir. Durmuş (2016) araştırmasında ailelerin çoğunluğunun çocuklarının eğitim sürecine hiçbir şekilde katılmadıklarını tespit etmiştir. Çakır (2017) tarafından yapılan yükssek lisans tez araştırmasında; katılımcı okul müdürleri, karara etki edecek şekilde velilerin yönetimde söz sahibi olmasını istemedikleri, velilerin sadece tavsiye niteliğindeki kararlarda söz sahibi olması gerektiği yönünde görüş beyan etmişlerdir.

Kolay (2004) okul-aile-çevre arasındaki işbirliğini okul koruma derneği ve Okul Aile Birliği (OAB) özelinde incelemiştir. Tican Başaran ve Koç (2001) tarafından yapılan araştırmada öğretmen ve yöneticiler, velilerden daha çok okula hizmet etme boyutuyla katılım beklerken, veliler daha çok karar alma süreçlerinde bulunma boyutuyla okul yönetimine katılmak istediklerini belirtmişlerdir. Abbak (2008) tarafından yapılan araştırmada okul öncesi öğretmenlerin yıllık planlarında veli katılımı ile ilgili hiç yer vermedikleri faaliyetlerden birisinin de yönetim ve karar süreçlerine katılım etkinliği olduğu tespit edilmiştir.

Yaylacı (1999) tarafından yapılan yüksek lisans tez araştırmasında katılımcı olan okul yöneticileri, öğretmenler ve veliler, okulda karar mekanizmalarına aile katılımının nadiren gerçekleştiğini belirtmişlerdir. Özyolcu (2017) tarafından ortaöğretim kurumları çalışanlarının katılımı ile yapılan yüksek lisans tez araştırmasında yönetime katılma ile çalışan tutumları arasında olumlu bir ilişki olduğu tespit edilmiştir. Yakıcı (2018) tarafından okul öncesi öğrenci velileri ile yapılan yüksek lisans tez araştırmasında katılımcı velilerin aile katılımının ev temelli boyutunda en yüksek düzeyde, okul temelli boyutunda en düşük düzeyde olduklarını tespit etmiştir. Bayrakçı ve Dizbay (2013) tarafından yapılan ve okul aile birlikleri özelinde yönetime 
katılma kavramının incelendiği araştırmada, okul aile birliklerinin sadece ekonomik konularda yönetime katıldıkları tespit edilmiştir.

Okul temelli aile katılımını arttırmak ve verimli hale getirmek için ulusal mevzuatta yer alan velilerin hak ve sorumlulukları ile ilgili bilgilendirmenin okul yöneticileri ve öğretmenler tarafından daha sık yapılması yararlı olacaktır. Aile katılımı konusunda velilerin daha çok bilgilendirilmeleri ve teşvik edilmeleri daha demokratik ve şeffaf bir eğitim politikası olarak benimsenmelidir (Şad ve Gürbüztürk, 2013).

Eğitim Bilimleri alanında, demokratik okul, okula dayalı / okul merkezli yönetim isimleri ile kavramlaştırılan okul yönetimi modellerinin, katılımcılığı esas aldığı, okul toplumu üyelerine (müdür, öğretmen, öğrenci, veli, diğer personel) karar alma mekanizmalarında yer verdiği görülmektedir. Türkiye'de okullar yürürlükte olan ulusal mevzuat hükümleri doğrultusunda yönetildiğinden velilerin yönetime katılım haklarına da yasalar çerçevesinde yer verilmektedir. Bu araştırmada Haziran 2019 tarihi itibarı ile Türkiye'de yürürlükte olan ulusal mevzuatta velilerin yönetime katılımını içeren maddelerin tespit edilerek incelenmesi amaçlanmıştır. Bu doğrultuda araştırma kapsamında aşağıdaki sorulara yanıtlar aranmıştır;

- Türkiye'de Haziran 2019 tarihi itibarı ile yürürlükte olan ulusal mevzuat içerisinde velilerin yönetime katılımını düzenleyen hükümler nelerdir?

- Türkiye'de velilerin yönetime katılımı ile ilgili yapılan araştırmalarda yürürlükte olan ulusal mevzuata yer verilme durumu nedir?

\section{Yöntem}

Araştırmada nitel araştırma yöntemlerinden doküman analizi yöntemi kullanılmıştır. Doküman analizi/incelemesi, araştırılması planlanan olgu ya da olgular hakkında bilgi içeren yazılı kaynakların analiz edilmesidir (Yıldırım ve Şimşek, 2005).

Normlar hiyerarşisine göre Türkiye'de Anayasa, yasa, yasa gücünde kararname, tüzük, yönetmelik, adsız düzenleyici işlemler (genel tebliğler, tebliğler, genelgeler vb.) ulusal mevzuatı oluşturmaktadır (Kuluçlu, 2008). Araştırmanın birinci alt amacı için dokümanlar Milli Eğitim Bakanlığı'nın (MEB) mevzuat bankasından elektronik ortamda elde edilmiştir (meb.gov.tr/mevzuat). Bu portalda yer alan ve 15 Haziran 2019 tarihi itibarı ile yürürlükte olan 1982 Anayasası, 25 adet kanun, iki adet kanun hükmünde kararname, beş adet 
Cumhurbaşkanlığı Kararnamesi, bir adet Cumhurbaşkanı Kararı, 15 adet bakanlar kurulu kararı, 121 adet yönetmelik, 80 adet yönerge, yedi adet tebliğg, 17 adet usül ve esas, 334 adet genelge içerik metinlerinden "veli” ve "aile" kelimesi aratılarak taranmıştır. Ulusal mevzuat belgeleri incelenirken normlar hiyerarşisine (Anayasa, yasa, yasa gücünde kararname, tüzük, bakanlar kurulu kararları, yönetmelik, yönerge, tebliğ, usül ve esas, genelge) uygun bir şekilde sistematik inceleme yapılmıştır. Mevzuat metinlerinde "veli" veya "aile" kelimesinin geçtiği cümleler yönetime katılma kavramı bağlamında incelenmiştir. Literatüre göre velilere yönetime katılma hakkının verildiği görülen metinler araştırma içeriğine dâhil edilmiştir.

Araştırmanın ikinci alt amacı için başlığında "Okul Aile Birliği”, "Okul Aile İşbirliği” veya “Okul Yönetimine Katılım” kelime gruplarından en az birini içeren ve 1990-2019 yılları arasında yayımlanan iki adet doktora tezi (Akbaşl1, 2007; Bilgin, 1990), iki adet yüksek lisans tezi (Kazak, 1998; Özdemir, 2018) ve dokuz adet makale (Arslanargun, 2007; Balkar, 2009; Bayrakçı ve Dizbay, 2013; Ceylan ve Akar, 2010; Çalışkan ve Ayık, 2015; Çınkır ve Nayır, 2017; Kartal, 2008; Kolay, 2004; Yıldırım ve Dönmez, 2008) ulusal mevzuata içerikte yer verilme durumlarına göre incelenmiştir. Her iki alt amaç için belirlenen veri kaynaklarından toplanan veriler içerik analizi ile analiz edilmiştir. İçerik analizi; insanların söyledikleri ve yazdıklarının bir yönergeye göre kodlandığı sayısallaştırma süreci olarak tanımlanabilir (Balcı, 2005).

\section{Bulgular}

Bu bölümde araştırma amaçları doğrultusunda Türkiye'de velilerin yönetime katılımı ile ilgili yapılan araştırmalarda ulusal mevzuata yer verilme durumu ve Haziran 2019 tarihi itibarı ile yürürlükte olan ulusal mevzuatın içerdiği velilerin yönetime katılım hakkını düzenleyen hükümler incelenmiştir.

Ceylan ve Akar (2010) tarafından yapılan ortaöğretimde okul-aile işbirliğinin incelendiği araştırmada konu ile ilgili mevzuat taramasının da yapıldığı belirtilmiştir. Ancak, araştırmada yapılan mevzuatla ilgili doküman incelemesinde nasıl bir yöntemin takip edildiği ve kapsamının belirtilmediği görülmektedir. Ayrıca okul-aile işbirliği ile ilgili hükümler içerebilecek ve araştırma tarihi itibarı ile yürürlükte olan Anadolu Öğretmen Liseleri Yönetmeliği, Fen Liseleri Yönetmeliği, Mesleki ve Teknik Eğitim Yönetmeliği, Sosyal Bilimler Liseleri Yönetmeliği, Ortaöğretim Kurumları Sınıf Geçme ve Sınav Yönetmeliği, 
Anadolu Liseleri Yönetmeliği, Okul Aile Birliği Yönetmeliği gibi yönetmeliklerin doküman incelemesine dâhil edilmediği araştırma metni incelendiğinde görülmektedir.

Çalışkan ve Ayık (2015) tarafından yapılan Okul Aile Birliği ve Velilerle İletişim başlıklı araştırmada ve Özdemir (2018) tarafından yapılan Okul Aile İşbirliğinin Geliştirilmesine Yönelik Yönetici Görüşleri isimli yüksek lisans tezinde yürürlükte olan mevzuatla ilgili doküman incelemesi yapılırken 2005 y1lında yayınlanan ve 2012 y1lında mülga (yürürlükten kaldırılan) yönetmeliğe ait hükümlerin incelenerek araştırmaya aktarıldığı, 2012 tarihinde yayımlanan yeni yönetmeliğe yer verilmediği görülmüştür.

Kartal (2008) tarafından ilköğretim ve ortaöğretim kurumlarında velilerin yönetime katılımının ilköğretim ve liselere ait yönetmelikler üzerinden incelendiği araştırmada yönetime katılım 1-Kurul Üyeliği, 2-Komisyon Üyeliği, 3- Yönetime Görüş ve Öneri Belirtme, 4Yönetime Yardımcı Olma boyutları ile incelendiği görülmektedir. Araştırma sonucunda Anadolu Liselerinde öğrenci kontenjanlarının tespitinde öğretmenle birlikte velilere de yer verildiği, Anadolu öğretmen liseleri ve ilköğretim kurumlarında velilerin yönetime katılmada daha çok yer aldığı tespit edilmiştir. Araştırmanın kapsamı örgün eğitim kurumları olarak belirtilmişken, araştırmanın yapıldığı ve yayınlandığı tarihte yürürlükte olan Mesleki ve Teknik Eğitim Yönetmeliği’nin ve velilerin yönetime katılması ile ilgili hükümler içeren Okul Aile Birliği Yönetmeliği’nin araştırma kapsamı dışında tutulduğu tespit edilmiştir.

Balkar (2009) tarafından yapılan "Okul Aile İşbirliği Sürecine İlişkin Veli Ve Öğretmen Görüşleri Üzerine Nitel Bir Çalışma” başlıklı makalenin kavramsal-kuramsal bölümünde konu ile ilgili ulusal mevzuata hiç yer verilmediği görülmüştür. Diğer taraftan araştırma bağlamında incelenen tez ve makaleler arasında ulusal mevzuata en kapsamlı yer veren çalışmaların Kartal (2008) ve Yıldırım ve Dönmez (2008) tarafından yapılan araştırmalar olduğu görülmüştür.

\section{Velilerin Yönetime Katılımı İle İlgili Ulusal Mevzuat}

Bu bölümde Türkiye'de yürürlükte olan ulusal mevzuat, MEB Stratejik Planları, Öğretmen Strateji Belgesi, Milli Eğitim Şura kararları velilerin yönetime katılımı ile ilgili hükümler bağlamında incelenmiştir.

MEB öğretmen yetiştirme ve geliştirme sürecinde yapılacak faaliyetler için bir yol haritası niteliğinde olan 2017-2023 yılları arasını kapsayan Öğretmen Strateji Belgesi’ni 2017 
yılında yayınlamıştır. Öğretmen Strateji Belgesi’nin taslak metnin çalışmasının yapıldı̆̆ çalıştayda öğrenci ve velilerin de katılımcı olarak bulunduğu belirtilmektedir (MEB, 2017a).

MEB'in en yüksek danışma kurulu olan 18. Milli Eğitim Şurasına (1-5 Kasım 2010) ait kararların İlköğretim ve Ortaöğretim Güçlendirilmesi, Ortaöğretime Erişimin Sağlanması” başlıklı bölümün 8 . maddesinde öğrencilerin ve velilerin okulda yönetim ve karar süreçlerine daha fazla katılımının sağlanması tavsiye edilmektedir (MEB, 2010). Diğer taraftan, MEB'in 2015-2019 Stratejik Planı, velilerin yönetime katılımı kapsamında incelenmiş velilerin yönetime katılımına yönelik stratejik hedef ve stratejiye rastlanılmamıştır (MEB, 2015).

İçerik analizi yöntemiyle yapılan incelemelerde 1982 Anayasası, yasalar, yasa gücünde kararnameler ve tüzüklerde velilerin okul yönetimine katılımını düzenleyen herhangi bir maddeye rastlanmamıştır. Ancak, Milli Eğitim Temel Kanunu. (1973). T.C. Resmi Gazete, 14574, 24 Haziran 1973 tarihli 1739 sayılı kanunun ikinci bölümünde yer alan milli eğitimin temel ilkelerinden birinin, okul aile işbirliğinin sağlanması olduğu görülmektedir. Yasalar içinde velilerin yönetme katılımı ile ilgili hükümler tarandıktan sonra sırasıyla yönetmelikler, yönergeler ve genelgeler bu bağlamda incelenmiştir.

\section{Milli Eğitim Bakanlığı Eğitim Kurumları Sosyal Etkinlikler Yönetmeliği’nde Veli} Katılımı. Milli Eğitim Bakanlığı Sosyal Etkinlikler Yönetmeliği. (2017). T.C. Resmi Gazete, 30090, 08 Haziran 2017 tarihinde yayımlanarak yürürlüğe girmiştir (MEB, 2017b). Yönetmelikte 01 Eylül 2018 tarihinde değişiklik yapılmıştır. Yönetmelikte veli katılımı ile ilgili olan sosyal etkinlik kurulunun oluşumu aşağıda açıklanmıştır.

Sosyal Etkinlikler Kurulu. Yönetmeliğin 6. maddesinin 1. fikrasına göre eğitim kurumu müdürünün veya görevlendireceği bir müdür yardımcısının başkanlığında, öğretmenler kurulunda danışman öğretmen olarak belirlenen öğretmenler arasından eğitim kurumu müdürünün belirlediği üç öğretmen, öğrenci kulübü temsilcilerinin kendi aralarından seçecekleri iki öğrenci ile okul-aile birliğince belirlenen bir veliden oluşur.

Milli Eğitim Bakanlığı Okul Aile Birliği Yönetmeliği’nde Veli Katılımı. Milli Eğitim Bakanlığı Okul Aile Birliği Yönetmeliği. (2012). T.C. Resmi Gazete, 28199, 9 Şubat 2012 tarihinde yayımlanarak yürürlüğe girmiştir (MEB, 2012a). Yönetmelikte 20 Kasım 2012 ve 14 Mart 2019 tarihinde olmak üzere iki sefer değişiklik yapılmıştır. Yönetmeliğin veli katılımı ile ilgili düzenlediği kurul ve komisyonlar aşağıda sıralanmıştır: 
Genel Kurul. Yönetmeliğin 9.maddesinde düzenlenmiştir. Okul yöneticileri, öğretmenler ve veliler ile on sekiz yaşını geçmiş kursiyer, çıraklık, kalfalık ve ustalık eğitimine devam eden kişiler birliğin tabii üyesidir.

Yönetim Kurulu. Yönetmeliğin 12'nci maddesine göre bu kurul, genel kurul tarafından seçilen beş asil beş yedek üyeden oluşur. Yönetim kurulu, sadece anne veya baba olan veliler ile istemeleri halinde okul yaptırarak Bakanlığa bağışta bulunan hayırseverler arasından seçilen beş üyeden oluşur.

Denetleme Kurulu. Yönetmeliğin 14'üncü maddesine göre öğretmenler kurulunca seçilen iki asıl, iki yedek öğretmen dışında, veliler arasından seçilen bir asıl, bir yedek üyeden oluşur.

İ/İlçe Milli Ĕğitim Müdürlüğü Kantin Gelirleri Komisyonu. Yönetmeliğin 17'nci maddesinin birinci fıkrasının $b$ bendinin üç numaralı alt bendine göre il/ilçe millî eğitim müdürünün veya görevlendireceği ilgili müdür yardımcısı/şube müdürü başkanlığında iki okul müdürü ve iki birlik başkanından, mülki amirin onayı ile oluşturulur.

Okul Aile Birliği Mal ve Hizmet Alım Komisyonu. Yönetmeliğin 18'nci maddesinin birinci fikrasına göre mal ve hizmet alımları birlik yönetim kurulu üyeleri veya uzmanlık gerektiren işlerde OAB üyelerinden oluşan en az üç kişilik bir komisyon marifetiyle yapılır.

Muhammen Bedel Tespit Komisyonu. Yönetmeliğin 19'uncu maddesine göre valilik/kaymakamlıkça görevlendirilecek il/ilçe millî eğitim müdür yardımcısı/şube müdürü başkanlığında okul müdürü/müdür yardımcısı, OAB başkanı ve yönetmelikte belirlenen diğer temsilcilerin katılımıyla oluşur.

Kantin Kiralama İhale Komisyonu. Yönetmeliğin 20'inci Maddesinin üçüncü fikrasına göre valilik/kaymakamlıkça görevlendirilecek il/ilçe millî eğitim müdür yardımcısı/şube müdürü başkanlığında ilgili OAB başkanı ve yönetmelikte belirlenen diğer temsilcilerin katılımıyla oluşur.

Okul Servis Araçları Kiralama Komisyonu. Yönetmeliğin 20'inci Maddesinin 10’uncu fıkrasına göre okul servis araçlarının kiralanması her yıl okul-aile birliği yönetim kurulu başkanının başkanlığında, okul-aile birliği yönetim kurulunca belirlenecek bir temsilci, okulaile birliği yönetim kurulunca çocuğu servisle taşınan veliler arasından tespit edilecek dört veli, varsa okul eğitim vakfi yönetim kurulunca belirlenecek bir temsilcinin katılımlarıyla 
oluşturulacak komisyon tarafından yapılır. Okul servis araçlarının kiralanmasında yapılacak sözleşmelerde $\mathrm{OAB}$ yetkilidir.

Milli Eğitim Bakanlığı Rehberlik Hizmetleri Yönetmeliğinde Veli Katılımı. Milli Eğitim Bakanlığı Rehberlik Hizmetleri Yönetmeliğii. (2017). T.C. Resmi Gazete, 30236, 10 Kasım 2017 tarihinde yayımlanarak yürürlüğe girmiştir (MEB, 2017b). Yönetmeliğin içerdiği veli katılım hükümleri aşağıda verilmiştir.

Rehberlik Hizmetleri Yürütme Komisyonu. Yönetmeliğin 29'uncu maddesine göre eğitim kurumu müdürünün başkanlığında; müdür başyardımcısı, sınıf ve şubelerden sorumlu müdür yardımcıları ve pansiyondan sorumlu müdür yardımcıları ile rehberlik hizmetlerinden sorumlu müdür yardımcısı, rehberlik öğretmenleri, sınıf rehber öğretmenlerinden her sınıf düzeyinden seçilecek en az birer temsilci, ortaöğretim kurumlarında disiplin kurulu ve onur kurulundan; ilköğretim kurumlarında ise öğrenci davranışları değerlendirme kurulundan birer temsilci, okul-aile birliğinden bir temsilci, okul öncesi eğitim kurumları hariç okul öğrenci temsilcisi katılımıyla oluşur.

Özel Eğitim Hizmetleri Yönetmeliğinde Veli Katılımı. Özel Eğitim Hizmetleri Yönetmeliği. (2018). T.C. Resmi Gazete, 30471, 7 Temmuz 2018 tarihinde yayımlanarak yürürlüğe girmiştir (MEB, 2018). Yönetmeliğin veli katılımı ile ilgili hükümleri aşağıda sıralanmıştır:

Yabancı Dil Dersinden Muafiyet. Yönetmeliğin 24'üncü maddesinin birinci bendinin ç fikrasına göre; işitme yetersizliğgi, zihinsel yetersizliği veya otizmi olan öğrenciler, her tür ve kademede velinin yazılı talebi ve BEP (Bireyselleştirilmiş Eğitim Programı) geliştirme biriminin kararına göre yabancı dil dersinden muaf tutulabilirler.

Ö̆̆rencinin Sınıf Tekrarına Kalma Durumu. Yönetmeliğin 24'üncü maddesinin birinci fıkrasının $\mathrm{f}$ bendine göre öğrencilere velinin yazılı talebi ve BEP geliştirme biriminin kararı doğrultusunda ilkokulda bir defaya mahsus olmak üzere sınıf tekrarı yaptırılabilir.

Özel Ĕ̌̆itim Hizmetleri Kurulu. Yönetmeliğin 39'uncu maddesine göre bu kurul özel eğitim ve rehberlik hizmetleri şube müdürünün başkanlığında; en az bir özel eğitim değerlendirme kurulu başkanı, en az bir resmi özel eğitim kurum müdürü veya kaynaştırma/bütünleştirme yoluyla eğitim yapılan kurumlardan bir müdür, en az bir rehberlik 
öğretmeni, en az bir özel eğitim öğretmeninden oluşur. Gerektiğinde görüşlerine başvurmak üzere bireyin velisinin ve ilgili kurumlardan personelin kurula katılımı sağlanır.

Özel Ĕğitim Değerlendirme Kurulu. Yönetmeliğin 43'üncü maddesine göre RAM (Rehberlik Araştırma Merkezi) müdürlüğünün teklifi ve il veya ilçe milli eğitim müdürlüğünün onayı ile RAM'larda oluşturulur. Bu kurul müdür yardımcısı başkanlığında; özel eğitim hizmetleri bölüm başkanı, en az bir rehberlik öğretmeni, en az bir özel eğitim öğretmeninden oluşur. Bu kurula ilgili bireyin velisi veya kendisi üye olarak katılır.

Bireyselleştirilmiş Ĕğtim Programı (BEP) Geliştirme Birimi. Yönetmeliğin 47'inci maddesine göre özel eğitim ihtiyacı olan öğrenciler için okulda BEP hazırlamak amacıyla BEP geliştirme birimi oluşturulur. BEP Geliştirme Birimi; okul müdürü veya görevlendireceği bir müdür yardımcısının başkanlığında, rehberlik öğretmeni, öğrencinin sınıf öğretmeni, öğrencinin dersini okutan alan öğretmenleri, öğrencinin velisi ve öğrenciden oluşur.

Okul Servis Araçları Yönetmeliğinde Veli Katılımı. Okul Servis Araçları Yönetmeliği. (2017). T.C. Resmi Gazete, 30221, 25 Ekim 2017 tarihinde yayımlanarak yürürlüğe girmiştir (MEB, 2017c). Yönetmelikte 14 Ağustos 2018 tarihinde bir kez değişiklik yapılmıştır. Yönetmeliğin veli katılımı ile ilgili hükümleri aşağıda verilmiştir:

Kreş, gündüz bakımevi ve çocuk kulübü taşımacıyı tespit komisyonu. Yönetmeliğin 3. maddesinin 1. fikrasının ç bendine göre her yıl ilgili kuruluş müdürü başkanlığında, grup sorumluları arasından kuruluş müdürü tarafından belirlenen bir grup sorumlusu, çocuğu servisle taşınan veliler arasından idarenin belirleyeceği üç velinin katılımı ile bu komisyon oluşturulur.

Taşımacıyı tespit komisyonu. Yönetmeliğin 3. maddesinin 1. fikrasının m bendine göre her yıl ilgili okul müdürünün başkanlığında, OAB başkanı, öğretmenler kurulunda seçilen bir öğretmen (bir asıl, bir yedek üye), çocuğu servisle taşınan veliler arasından okul yönetiminin belirleyeceği iki velinin (iki asıl, iki yedek üye) ve varsa okul eğitim vakfı yönetim kurulunca belirlenecek bir temsilcinin katılımıyla bu komisyon oluşturulur.

Milli Eğitim Bakanlığı'na Bağlı Resmi Okullarda Yatılılık, Bursluluk, Sosyal Yardımlar ve Okul Pansiyonları Yönetmeliği’nde Veli Katılımı. Milli Eğitim Bakanlığı’na Bağlı Resmi Okullarda Yatılılık, Bursluluk, Sosyal Yardımlar ve Okul Pansiyonları 
Yönetmeliği. (2016). T.C. Resmi Gazete, 9185858, 29 Ekim 2016 tarihinde yürürlüğe girmiştir (MEB,2016). Yönetmeliğin veli katılımı ile ilgili hükmü şöyledir;

Pansiyonlarda Konaklama, Tahsis ve Devir. Yönetmeliğin 35'inci maddesine göre, okul yönetimi OAB ile işbirliği yaparak 1 Temmuz - 31 Ağustos tarihleri arasında okul pansiyonunda konaklamayla ilgili düzenleme yapabilir.

\section{Milli Eğitim Bakanlığı Okul Öncesi Eğitim Kurumları ve İlköğretim Kurumları} Yönetmeliği'nde Veli Katılımı. Milli Eğitim Bakanlığı Okul Öncesi Eğitim Kurumları ve İlköğretim Kurumları Yönetmeliği. (2014). T.C. Resmi Gazete, 29072, 26 Temmuz 2014 tarihinde yürürlüğe girmiştir (MEB, 2014a). Yönetmelikte 23 Ekim 2014, 25 Haziran 2015, 16 Haziran 2016 ve 31 Ocak 2018 tarihlerinde olmak üzere toplam dört kez değişiklik yapılmıştır. Yönetmeliğin son halinde veli katılımı ile ilgili hükümler şöyledir:

Şube Ö̆̆retmenler Kurulu. Yönetmeliğin 36'nc1 maddesinin 1. fikrasına göre; şube öğretmenler kurulu, ortaokul ve imam-hatip ortaokullarında aynı şubede ders okutan öğretmenler ile okul rehber öğretmeninden oluşur. Kurula, gerek görülürse veliler ile öğrenciler arasından seçilen temsilciler de çağrılabilir.

Öğrencilerin Ödüllendirilmesi. Yönetmeliğin 51'inci maddesinin birinci fikrasına göre; bakanlığa bağlı resmî ve özel ilköğretim kurumlarında öğrencilerin ödüllendirilmesi, davranışlarının izlenmesi, değerlendirilmesi ve geliştirilmesine yönelik faaliyetler; öğrenci, veli, öğretmen ve yönetici iş birliğinde yürütülür.

Ö̆̆renci Davranışlarını Değerlendirme Kurulu. Yönetmeliğin 57'inci maddesine göre; ortaokul ve imam-hatip ortaokullarında varsa müdür başyardımcısı veya müdürün görevlendireceği müdür yardımcısının başkanlığında, her ders yılının ilk öğretmenler kurulunda gizli oyla seçilecek üç öğretmen, OAB’nin kendi üyeleri arasından seçeceği bir veliden oluşturulur.

Ücret Tespit Komisyonu. Yönetmeliğin 67'inci maddesine bu komisyon, okulun bulunduğu il/ilçe millî eğitim müdürünün başkanlığında; okul öncesi eğitimden sorumlu il millî eğitim müdür yardımcısı veya şube müdürü, anaokulu ve bünyesinde anasınıfı bulunan her derece ve türden birer okul müdürü ve alan/bölüm şefi ile anaokulu, ana sınıfı ve uygulama sınıfı öğretmenleri arasından seçilecek birer temsilci, iki OAB başkanı ve varsa bu işte görevli memur veya döner sermaye saymanından oluşur. 
Ortaöğretim Kurumları Yönetmeliğinde Veli Katılımı. Ortaöğretim Kurumları Yönetmeliği. (2013). T.C. Resmi Gazete, 28758, 7 Eylül 2013 tarihinde yürürlüğe girmiştir (MEB, 2013a). Yönetmelik 19 Şubat 2014, 21 Haziran 2014, 13 Eylül 2014, 1 Temmuz 2015, 28 Ekim 2016, 26 Mart 2017, 16 Eylül 2017, 14 Şubat 2018 ve 1 Eylül 2018 tarihlerinde olmak üzere dokuz sefer değiştirilmiştir. Yönetmeliğin 25 Haziran 2019 tarihli son halinde veli katılımı ile ilgili hükümler aşağıda sıralanmıştır:

Zararlı Alışkanlıklardan Korunma. Yönetmeliğin 17'inci maddesine göre ortaöğretim kurumlarında güvenli ortamın sağlanmasına yönelik koruyucu ve önleyici tedbirlerin alınması, zararlı alışkanlıkların önlenmesi ve öğrencilerin şiddetten korunması amacıyla rehberlik hizmetleri kapsamında okul merkezli, temel önleme çalışmaları yürütülür. Bu konuda okul yönetimi, öğretmen, veli ve çevre ile işbirliği yaparak gerekli önlemleri alır.

Seçmeli Derslerin Tespiti. Yönetmeliğin 11'inci maddesine göre ders seçimi okulun imkânlarına bağlı olarak veli, sınıf rehber öğretmeni ve rehberlik öğretmeninin bilgisi dâhilinde öğrenci tarafından şubat ayı içinde yapılır.

Sosyal Etkinlikler. Yönetmeliğin 18'inci maddesine göre öğrenci kulüp faaliyetleri, topluma hizmet etkinlikleri, geziler, törenler ile diğer bilimsel, sosyal, kültürel, sanatsal ve sportif etkinlikler öğretmen, öğrenci, veli ve ilgili çevrenin katılımıyla okulda ya da okul müdürlüğünce belirlenen, eğitim ve öğretimin amaçlarına uygun mekânlarda yapılır. Ancak etkinlikler sırasında öğrencilerin her türlü zararlı alışkanlıklar, olumsuz davranışlar ve aşırılıklardan korunması, israftan kaçınılması için okul yönetimince öğretmenler ve velilerle iş birliği yapılarak gerekli tedbirler alınır.

Okul Spor Kulübü. Yönetmeliğin 18'inci maddesinin 2. fikrasına göre öğrenci, öğretmen, veli ve okul yöneticilerinin katılımı ile 31/3/2005 tarihli ve 25772 sayılı Resmî Gazete'de yayımlanan Dernekler Yönetmeliği hükümlerine göre okul spor kulübü kurulabilir.

Kontenjan Belirleme Komisyonu. Yönetmeliğin 24'üncü maddesinin 1. fikrasının a bendine göre; okul müdürünün başkanlığında bir müdür yardımcısı, bir rehberlik öğretmeni, öğretmenler kurulunca seçilen bir öğretmen, varsa alan/bölüm şefi, OAB' yi temsilen bir velinin katılımıyla kontenjan belirleme komisyonu oluşturulur.

Okul Birincisinin Tespiti. Yönetmeliğin 64'üncü maddesinde okul birincisini tespit etme usul ve esasları belirtilmektedir. Okul birincisinin tespit edilmesinde eşitliğin bozulmaması hâlinde ilgili öğrenci ve velilerin de katılımıyla öğretmenler kurulunda kura çekilerek okul birincisi tespit edilir denilmektedir. 
Ö̆̆retmenler Kurulu. Yönetmeliğin 109'uncu maddesinin 1. F1krasında sayılan personelin katılımıyla öğretmenler kurulu toplanır. Aynı maddenin 2. fikrasında; gerektiğinde ilgili gündem maddelerinde görüş ve düşüncesine başvurulmak üzere pansiyon öğrenci temsilcisi ile OAB başkanı da kurul toplantısına çağrılır denilmektedir.

Sinıf/Şube Öğretmenler Kurulu. Yönetmeliğin 110'uncu maddesine göre sinıf öğretmenler kurulu aynı sınıf seviyesinde, şube öğretmenler kurulu ise aynı şubede ders okutan öğretmenler ile rehberlik öğretmenlerinden oluşur. Aynı maddenin 5. fikrasında görüşülen konuların özelliğine göre öğrenci velileri ile ilgili sınıfta/şubede derse giren eğitici personel de kurul toplantılarına davet edilebilir denilmektedir.

Okul Öğrenci-Veli Sözleşmesi. Yönetmeliğin 157'inci maddesinin 4. fikrasında okul yönetimi, öğrencilerin uyacakları kurallar ve öğrencilerden beklenen davranışlarla bunlara uyulmaması durumunda öğrencilerin karşılaşabilecekleri yaptırımlar konusunda kendilerini ve velilerini bilgilendirir. Ayrıca bu hususlara okul veli sözleşmesinde yer verilir. Yine aynı maddenin 6. fikrasında öğrenci ve veliler okul öğrenci veli sözleşmesinin gereklerini yerine getirir denilmektedir. Ayrıca; MEB’in 2005/92 sayılı genelgesi ile yürürlüğe giren öğrenci-veli okul sözleşmesinin amaçlarından birinin öğrenci ve velinin okulun işleyişine etkin katılımını sağlamak olduğu belirtilmektedir (MEB, 2005).

Ö̆̆rencilerin Korunması. Yönetmeliğin 157'inci maddesinin 1. fikrasının ç bendinde; yönetici ve öğretmenlerce, öğrencilerin; çevre, okul çalışanları ve diğer öğrenciler tarafından fiziksel ve ruhsal yönden zarar görmemeleri için dedikoduya, zorbalığa, tehdide, sataşmaya ve onur kırıcı her türlü lakap takılmasına karşı korunması konularında veli veya aileyle diğer ilgili kurum ve kuruluşlarla da işbirliği yapılarak gerekli tedbirler alınır denilmektedir.

Ceza Takdirinde Veli Görüşü. Yönetmeliğin 168'inci maddesinin 1. fikrasının ç bendinde; disiplin cezaları takdir edilirken sınıf rehber öğretmeni, gerektiğinde diğer öğretmenler ve velinin görüşleri göz önünde bulundurulur denilmektedir.

Okul Öğrenci Ödül ve Disiplin Kurulu. Yönetmeliğin 168'inci maddesinin 1. fikrasına göre, müdür başyardımcısı veya müdürün görevlendireceği müdür yardımcısı, her ders yılının ilk ayı içinde öğretmenler kurulunca gizli oyla seçilecek iki öğretmen, onur kurulu ikinci başkanı, OAB’nin kendi üyeleri arasından seçeceği bir velinin katılımıyla oluşturulur.

Milli Eğitim Bakanlığına Bağlı Okul Öğrencilerinin Kılık ve Kıyafetlerine Dair Yönetmelikte Veli Katılımı. Milli Eğitim Bakanlığına Bağlı Okul Öğrencilerinin Kılık ve Kıyafetlerine Dair Yönetmelik. (2012). T.C. Resmi Gazete, 28480, 27 Kasım 2012 tarihinde yürürlüğe girmiştir (MEB, 2012b). Yönetmelikte 25 Temmuz 2013 ve 27 Eylül 2014 
tarihlerinde olmak üzere iki kez değişiklik yapılmıştır. Yönetmeliğin içerdiği veli katılımı ile ilgili hüküm aşağıda gösterilmiştir:

Ö̆̆renci Okul Kıyafeti. Yönetmeliğin 3. maddesinin 2. fikrasına göre; öğrenciler okul, sınıf ve şubelerde tek tip kıyafet giymeye zorlanamaz. Ancak, okul yönetimi ve OAB'nin koordinatörlüğünde, velilerin yüzde ellisinden fazlasının onayı alınarak ilgili eğitim öğretim yılı için okul kıyafeti veya kıyafetleri belirlenebilir denilmektedir. Ayrıca MEB'in 2013/24 sayılı genelgesi ile okul kıyafetlerinin belirlenmesi için yapılacak oylamanın dört yılda bir yapılması hükme bağlanmıştır.

\section{Milli Eğitim Bakanlığı Özel Eğitim Kurumları Yönetmeliğinde Veli Katılımı. Milli} Eğitim Bakanlığı Özel Eğitim Kurumları Yönetmeliği. (2012). T.C. Resmi Gazete, 28296, 18 Mayıs 2012 tarihinde yayımlanarak yürürlüğe girmiştir (MEB, 2012c). Yönetmelikte, 4 Aralık 2012, 24 Mayıs 2013, 29 Mayıs 2014 ve 5 Temmuz 2018 tarihlerinde olmak üzere toplamda dört sefer değişiklik yapılmıştır. Yönetmeliğin veli katılımı ile ilgili hükmü aşağıdadır:

BEP Geliştirme Birimi. Yönetmeliğin 18'inci maddesine göre; özel eğitim okullarında birim, kurum müdürü veya görevlendireceği müdür yardımcısı başkanlığında; rehber öğretmen, öğrencinin sınıf öğretmeni, öğrencinin dersini okutan ilgili alan öğretmenleri, veli/vasi ve öğrenciden oluşur denilmektedir.

Milli Eğitim Bakanlığı Okul Kütüphaneleri Yönetmeliğinde Veli Katılımı. Milli Eğitim Bakanlığı Okul Kütüphaneleri Yönetmeliği. (2001). T.C. Resmi Gazete, 24501, 22 Ağustos 2001 tarihinde yayımlanarak yürürlüğe girmiştir (MEB, 2001). Yönetmelikte 27 Temmuz 2016 ve 29 Ocak 2009 tarihlerinde olmak üzere toplamda iki sefer değişiklik yapılmıştır. Yönetmeliğin veli katılımı ile ilgili hükmü şöyledir:

Kütüphane Kaynaklarının Tespiti Komisyonu. Yönetmeliğin 10. maddesine göre; okul müdürünün başkanlığında ilgili zümre başkanları, kütüphanecilik kulübü danışman öğretmeni, kütüphanecilik kulübü temsilcisi, OAB'den bir üye, okul öğrenci meclis başkanı, kütüphaneci veya kütüphane memurundan oluşturulur. Kitap seçiminde öğretmen, öğrenci ve velilerden gelen istekler de dikkate alınır denilmektedir.

Milli Eğitim Bakanlı̆̆ı Okul Öncesi Eğitim ve İlköğretim Kurumları Çocuk Kulüpleri Yönergesinde Veli Katılımı. Milli Eğitim Bakanlığı Okul Öncesi Eğitim ve İlköğretim Kurumları Çocuk Kulüpleri Yönergesi. (2014). T.C. Resmi Gazete, 3557646, 26 Ağustos 2014 tarihinde yayımlanarak yürürlüğe girmiştir (MEB, 2014b). Yönergede 10 Mart 2016 tarihinde bir sefer değişiklik yapılmıştır. Yönergede velilerin katılımı ile ilgili tek düzenleme şu şekildedir; 
Çocuk Kulübü Yönetim Kurulu. Yönergenin 11. maddesinin 1. fikrasına göre, okul müdürünün başkanlığında bir müdür yardımcısı, kulüpte görevli bir öğretmen veya koordinatör öğretmen ile çocuklarını kulübe kaydettiren velilerin kendi aralarında seçecekleri iki veli temsilcisinden oluşur denilmektedir.

\section{Milli Eğitim Bakanlığına Bağlı Eğitim Kurumlarında, Tanıtım, Mezunları İzleme,} İstihdam, Mesleki Rehberlik ve Danışma Hizmetleri Yönergesi’nde Veli Katılımı. Bu yönerge MEB'in 08/07/2009 Tarih ve 1769 sayılı makam onayı ile yürürlüğe girmiştir (MEB, 2009). Yönergede veli katılımı ile ilgili düzenleme aşağıda gösterilmiştir:

\section{Tanıtım, Mezunları İzleme, İstihdam, Mesleki Rehberlik Danışma Komisyonu.}

Yönergenin 6'ıncı maddesinin 1. fikrasına göre; okul / kurum müdürünün görevlendireceği bir müdür yardımcısının başkanlığında; ders yılı başlamadan önce yapılan ilk öğretmenler kurulunda önerilen üç öğretmen ile bir rehber öğretmenden Tanıtım, Mezunları İzleme, İstihdam, Mesleki Rehberlik ve Danışma Komisyonu oluşturulur. OAB başkanı bu komisyonun daimi üyesidir.

Görüldüğü üzere yapılan tarama, velilerin yönetime katılım hakkını düzenleyen maddelerin daha çok yönetmeliklerce düzenlendiğini göstermektedir. Türkiye'de Haziran 2019 tarihi itibarı ile yürürlükte olan ulusal mevzuat içerisinde velilerin yönetime katılım hakkını düzenleyen hükümler Tablo 1'de Kartal'ın (2008) kategorik sınıflandırmasına uygun bir şekilde gösterilmiştir.

Tablo 1.

Ulusal Mevzuat İçinde Velilerin Yönetime Katılma Hakkını Düzenleyen Hükümler

\begin{tabular}{|c|c|c|c|c|c|}
\hline ULUSAL MEVZUAT ADI ${ }^{1}$ & $\begin{array}{l}\text { VELILERIN YÖNETIME KATILMASINI } \\
\text { DÜZENLEYEN HÜKÜMLER }\end{array}$ & $\begin{array}{l}\text { KURUL } \\
\text { ÜYELiĞi }\end{array}$ & $\begin{array}{l}\text { KOMISYON } \\
\text { ÜYELIĞi }\end{array}$ & $\begin{array}{l}\text { YÖNETIME } \\
\text { GÖRÜŞ VE } \\
\text { ÖNERi } \\
\text { BİLDIRME }\end{array}$ & $\begin{array}{c}\text { YÖNETIME } \\
\text { YARDIMCI } \\
\text { OLMA }\end{array}$ \\
\hline \multirow{8}{*}{1} & Zararlı alışkanlıklardan korunma & & & & $x$ \\
\hline & Seçmeli derslerin tespiti & & & $x$ & \\
\hline & Sosyal etkinlikler & & & & $x$ \\
\hline & Okul Spor Kulübü & $x$ & & & \\
\hline & Kontenjan Belirleme Komisyonu & & $\mathrm{x}$ & & \\
\hline & Okul birincilerinin tespiti & & & & $\mathrm{x}$ \\
\hline & Sınıf/Şube Öğretmenler Kurulu & $x$ & & & \\
\hline & Okul veli sözleşmesi & & & & $x$ \\
\hline
\end{tabular}

\footnotetext{
1 1-Ortaöğretim Kurumları Yönetmeliği, 2-Okul Aile Birliği Yönetmeliği, 3-Özel Eğitim Hizmetleri Yönetmeliği, 4-Okul Öncesi Eğitim ve İlköğretim Kurumları Yönetmeliği, 5-Okul Servis Araçları Yönetmeliği, 6-Milli Eğitim Bakanlığı'na Bağlı Resmi Okullarda Yatılılık, Bursluluk, Sosyal Yardımlar ve Okul Pansiyonları Yönetmeliği, 7-Rehberlik Hizmetleri Yönetmeliği, 8-Eğitim Kurumları Sosyal Etkinlikler Yönetmeliği, 9Milli Eğitim Bakanlığı'na Bağlı Okul Öğrencilerinin Kılık ve Kıyafetlerine Dair Yönetmelik, 10-Özel Eğitim Kurumları Yönetmeliği, 11-Okul Kütüphaneleri Yönetmeliği, 12-Okul Öncesi Eğitim ve İlköğretim Kurumları Çocuk Kulüpleri Yönergesi, 13-Milli Eğitim Bakanlığı'na Bağlı Eğitim Kurumlarında Tanıım, Mezunları İzleme, İstihdam, Mesleki Rehberlik ve Danışma Hizmetleri Yönergesi.
} 


\begin{tabular}{|c|c|c|c|c|c|}
\hline & \multicolumn{4}{|l|}{ Öğrencilerin korunması } & \multirow[t]{3}{*}{$\mathrm{x}$} \\
\hline & Ceza takdirinde veli görüşü & & & $\mathrm{x}$ & \\
\hline & Okul öğrenci ve disiplin kurulu & $x$ & & & \\
\hline \multirow{9}{*}{2} & Genel Kurul & $x$ & & & \\
\hline & Yönetim Kurulu & $x$ & & & \\
\hline & Denetleme Kurulu & $x$ & & & \\
\hline & İlçe MEM Kantin Gelirleri Komisyonu & & $x$ & & \\
\hline & İl MEM Kantin Gelirleri Komisyonu & & $x$ & & \\
\hline & Okul Aile Birliği Mal ve Hizmet Alım Komisyonu & & $x$ & & \\
\hline & Muhammen Bedel Tespit Komisyonu & & $x$ & & \\
\hline & Kantin Kiralama Ihale Komisyonu & & $x$ & & \\
\hline & Okul Servis Araçları Kiralama Komisyonu & & $x$ & & \\
\hline \multirow{5}{*}{3} & Yabancı dil dersinden muafiyet & & & $x$ & \\
\hline & Öğrencinin sınıf tekrarına kalma durumu & & & $x$ & \\
\hline & Özel Eğitim Hizmetleri Kurulu & $x$ & & & \\
\hline & Özel Eğitim Değerlendirme Kurulu & $x$ & & & \\
\hline & BEP Geliştirme Birimi & $x$ & & & \\
\hline \multirow{4}{*}{4} & Şube Öğretmenler Kurulu & $x$ & & & \\
\hline & Öğrencilerin Ödüllendirilmesi & & & & $x$ \\
\hline & Öğrenci Davranışlarını Değerlendirme Kurulu & $x$ & & & \\
\hline & Ücret Tespit Komisyonu & & $x$ & & \\
\hline \multirow[t]{2}{*}{5} & $\begin{array}{l}\text { Kreş, Gündüz Bakımevi ve Çocuk Kulübü Taşımacıyı } \\
\text { Tespit Komisyonu }\end{array}$ & & $x$ & & \\
\hline & Taşımacıyı Tespit Komisyonu & & $x$ & & \\
\hline 6 & Pansiyonlarda konaklama, tahsis ve devir & & & & $\mathrm{x}$ \\
\hline 7 & Rehberlik Hizmetleri Yürütme Komisyonu & & $x$ & & \\
\hline 8 & Sosyal Etkinlikler Kurulu & $x$ & & & \\
\hline 9 & Öğrenci okul kıyafeti & & & $x$ & \\
\hline 10 & BEP Geliştirme Birimi & $x$ & & & \\
\hline 11 & Kütüphane Kaynaklarının Tespiti Komisyonu & & $x$ & & \\
\hline 12 & Çocuk Kulübü Yönetim Kurulu & $x$ & & & \\
\hline 13 & Mesleki Rehberlik Danışma Komisyonu & & $x$ & & \\
\hline
\end{tabular}

Tablo 1'de görüldüğü gibi Türkiye'de eğitimle ilgili ulusal mevzuatta Haziran 2019 tarihi itibarı ile yürürlükte olan ve normlar hiyerarşisine uygun olarak taranan 39 hüküm- konu velilerin yönetime katılma hakkını düzenlemektedir. Bu 39 hükmün 11'inin Orta Öğretim Kurumları Yönetmeliğinde, dokuzunun Okul Aile Birliği Yönetmeliğinde, beşinin Özel Eğitim Hizmetleri Yönetmeliğinde, dördünün Okul Öncesi Eğitim ve İlköğretim Kurumları Yönetmeliğinde, ikisinin Okul Servis Araçları Yönetmeliğinde yer aldığı diğer yönetmelik ve yönergelerde birer hükmün yer aldığı görülmektedir. Tablo 1'de ayrıca Kartal'ın (2008) yönetime katılma sınıflandırmasına uygun olarak velilerin yönetime katılımı ile ilgili mevzuat hükümlerinin 14'ünün kurul üyeliğgi, 13'ünün komisyon üyeliği, beşinin yönetime görüş ve öneri bildirme, yedisinin yönetime yardımcı olma kategorisinde yer aldığı görülmektedir. 


\section{Tartışma ve Sonuç}

Normlar hiyerarşisine uygun olarak mevzuat belgelerinin tarandığı bu araştırmada anayasa, yasa, tüzük gibi üst metin belgelerin daha genel ve öz maddeler içerdiği için velilerin yönetime katılımının daha çok yönetmeliklerle düzenlendiği görülmektedir. Veliler okul yönetimine daha çok kurul ve komisyonlar vasıtasıyla katılmakta; yönetici, öğretmen ve öğrenci ile birlikte görev almaktadırlar. Ancak OAB yönetim kurulu sadece velilerden oluşturulmaktadır. Kurul ve komisyonlara üyeler belirlenirken üyelerin temsil ettiği kitlenin büyüklüğünün dikkate alınmadığı dolayısıyla temsil oranının göz ardı edildiği görülmektedir.

Türkiye' de eğitimle ilgili ulusal mevzuatta haziran 2019 tarihi itibarı ile yürürlükte olan ve normlar hiyerarşisine uygun olarak taranan 39 hükmün- konunun velilerin yönetime katılma hakkını düzenlediği görülmüştür. $\mathrm{Bu} 39$ hükmün 11'inin Orta Öğretim Kurumları Yönetmeliğinde, dokuzunun Okul Aile Birliği Yönetmeliğinde, beşinin Özel Eğitim Hizmetleri Yönetmeliğinde, dördünün Okul Öncesi Eğitim ve İlköğretim Kurumları Yönetmeliğinde, ikisinin Okul Servis Araçları Yönetmeliğinde yer aldığı diğer yönetmelik ve yönergelerde birer hükmün yer aldığı görülmektedir.

Velilerin yönetime katılım hakkını düzenleyen 39 adet mevzuat maddesinin Kartal'ın (2008) kategorik sınıflandırmasına göre 14'ünün kurul üyeliği, 13'ünün komisyon üyeliği, beşinin yönetime görüş ve öneri bildirme, yedisinin yönetime yardımcı olma kategorisinde yer aldığı görülmüştür. Velilerin yönetime katılma hakkını düzenleyen maddelerin en çok 11 madde ile Orta Öğretim Kurumları Yönetmeliğinde bulunduğu onu dokuz madde ile Okul Aile Birliği Yönetmeliği’nin takip ettiği tespit edilmiştir.

Kartal (2008) tarafından ilköğretim ve ortaöğretim kurumlarında velilerin yönetime katılımının yönetmelikler üzerinden incelendiği araştırmada araştırmanın kapsamı örgün eğitim kurumları olarak belirtilmişken, araştırmanın yapıldığı ve yayınlandığı tarihte yürürlükte olan Mesleki ve Teknik Eğitim Yönetmeliği'nin ve velilerin yönetime katılması ile ilgili hükümler içeren Okul Aile Birliği Yönetmeliği’nin araştırma kapsamında yer verilmemesi nedeniyle ulusal mevzuat taramasının eksik yapıldığı görülmüştür.

Çalışkan ve Ayık (2015) tarafından yapılan araştırma ile Özdemir (2018) tarafından yapılan araştırmada yürürlükte olan mevzuatla ilgili doküman incelemesi yapılırken 2005 
yılında yayınlanan ve 2012 yılında yürürlükten kaldırılan mülga yönetmeliğe ait hükümlerin incelenerek makaleye aktarıldığı, 2012 tarihinde yayımlanan yeni yönetmeliğin görmezden gelinerek hatalı tarama yapıldı̆̆ 1 tespit edilmiştir.

Ceylan ve Akar (2010) tarafından yapılan Ortaöğretimde Okul-Aile İşbirliği İle İlgili Öğretmen ve Veli Görüşlerinin İncelenmesi başlıklı araştırmada konu ile ilgili mevzuat taramasının da yapıldığı belirtilmiştir. Ancak, Okul-Aile İşbirliği ile ilgili hükümler içerebilecek ve araştırma tarihi itibarı ile yürürlükte olan Anadolu Öğretmen Liseleri Yönetmeliği, Fen Liseleri Yönetmeliği, Mesleki ve Teknik Eğitim Yönetmeliği, Sosyal Bilimler Liseleri Yönetmeliği, Ortaöğretim Kurumları Sınıf Geçme ve Sınav Yönetmeliği, Anadolu Liseleri Yönetmeliği, Okul Aile Birliği Yönetmeliği gibi yönetmeliklerin doküman incelemesine dâhil edilmediği araştırma metni incelendiğinde görülmektedir.

\section{Öneriler}

Yapılan bu araştırma sonucundan hareketle; bundan sonra yapılacak araştırmalarda araştırma konusu yasal düzenlemelerle de ilgili ise, normlar hiyerarşisine uygun şekilde mevzuat belgelerinin incelenmesi önerilmektedir. Mevzuat metinleri üzerinden yapılan belge incelemelerinde Devletin resmi web siteleri olan mevzuat.gov.tr, resmigazete.gov.tr, meb.gov.tr/mevzuat internet adresleri gibi devlete ait sitelerin kullanılması, aynı zamanda mevzuatta yapılan değişikliklerin metin içerisine işlendiğinden emin olduktan sonra incelemeye geçilmesi tavsiye edilmektedir. Diğer taraftan mülga, yani yürürlükten kaldırılan yönetmeliklere de ayrıca dikkat edilmesi gerekmektedir.

Türkiye'de haziran 2019 tarihi itibarı ile yürürlükte olan ulusal mevzuat metinleri taranarak tespit edilen velilerin yönetime katılımı ile ilgili 39 hüküm- konu hakkında yönetici, öğretmen ve veli görüşlerinin alındığı nitel ve nicel araştırmalar yapılabilir. Yapılacak araştırmalarda velilerin yönetime katılım haklarının işlerlik analizleri yapılarak okullarda katılımcılığın gerçek katılım düzeyinde mi, göstermelik katılım düzeyinde mi olduğu açığa çıkarılabilir.

Velilerin yönetime daha çok kurul ve komisyonlar aracılığıyla katıldığı, kurul ve komisyonlarda yönetici, öğretmen ve velinin birlikte görev yaptıkları görülmektedir. Bunun tek istisnası $\mathrm{OAB}$ yönetim kuruludur. Bağımsız olarak maddi kaynak temin eden ve bu 
kaynakları kullanan yönetim kurulunun verimlilik, örgütsel çatışma, örgütsel iklim kavramları açısından incelenmesin de alana katkı sağlayacağı düşünülmektedir.

\section{Makalenin Bilimdeki Konumu}

Eğitim Bilimleri, Eğitim Yönetimi Anabilim Dalı

\section{Makalenin Bilimdeki Özgünlüğü}

Türkiye'de eğitim bilimleri alanında yapılan araştırmalarda doküman incelemesi yapılırken zaman zaman konu ile ilgili ulusal mevzuatta taranmaktadır. Yapılan araştırmalarda, araştırmacıların mevzuat tararken nasıl bir yöntem izlediği bu araştırmada öğrenci velilerinin okul yönetimine katılımı konusunda yapılan araştırmalar üzerinden incelenmiştir. Ayrıca normlar hiyerarşisi takip edilerek öğrenci velilerinin yönetime katılımını düzenleyen hükümlerin ulusal mevzuat metinleri üzerinden sistematik olarak çıkartıldığı bu araştırma bu yönüyle özgün bir nitelik taşımaktadır.

\section{Kaynakça}

Abbak, B. S. (2008). Okul Öncesi Eğitim Programındaki Aile Katılımı Etkinliklerinin Anasınıfı Öğretmenleri ve Veli Görüşleri Açısından İncelenmesi. (Yayımlanmamış yüksek lisans tezi). Çukurova Üniversitesi, Sosyal Bilimler Enstitüsü, Adana.

Akbaşl1, S.(2007). Ortaöğretim okullarındaki okul aile birliklerinin görevlerini gerçekleştirme düzeyleri. (Yayımlanmamış doktora tezi). Hacettepe Üniversitesi, Ankara.

Akbaşlı, S., Kavaklı, Y. (2008). Ortaöğretim okullarındaki okul aile birliklerinin görevlerini gerçekleştirme düzeyleri, Selçuk Üniversitesi Sosyal Bilimler Enstitüsü Dergisi, 19(19). $1-21$.

Argon, T., Kıyıcı, C. (2012). İlköğretim kurumlarında ailenin eğitim sürecine katılımlarına yönelik öğretmen görüşleri. Dicle Üniversitesi Ziya Gökalp Eğitim Fakültesi Dergisi, 19 (2012), 80-95.

Arslanargun, E. (2007). Okul aile işbirliği ve öğrenci başarısı üzerine bir tarama çalışması. Sosyal Bilimler Dergisi, 18(18). 119-135.

Aşlamacı, İ., Eker, E. (2017). İmam-Hatip Lisesi öğrenci velilerinin çocuklarının eğitimine katılım durumları: Okul yöneticilerinin görüşlerine dayalı nitel bir araştırma. Journal of 
Education in Muslim Societies and Communities, 1(2), 153-185. http://dx.doi.org/10.12738/talim.2017.2.0007

Aytaç, T. (1999). Okul merkezli yönetim. Ĕ̈itim ve Bilim, 23(111). 69-75.

Babaoğlan, E., Çelik, E., ve Nalbant, A. (2018). İdeal öğrenci velisi üzerine nitel bir çalışma. E-Uluslararası Ĕ̈itim Araştırmaları Dergisi, 9(1), 51-65. Doi. 10.19160/ijer.370497.

Balcı, A. (2005). Sosyal bilimlerde araştırma yöntem teknik ve ilkeler (5. Baskı), Pegem A Yayıncılık, Ankara.

Balkar, B. (2009). Okul-aile işbirliği sürecine ilişkin veli ve öğretmen görüşleri üzerine nitel bir çalışma. Çukurova Üniversitesi Eğitim Fakültesi Dergisi, 3(36), 105-123.

Başaran, İ.E. (1992). Yönetimde insan ilişkileri, Ankara: Kadığlu Matbaası.

Bayrakçı, M., Dizbay, S. (2013). Ortaöğretim kurumlarında okul aile birliklerinin yönetime katılım düzeyleri, Sakarya University Journal Of Education, 3 (1), 98-112.

Bilgin, M. (1990). Ankara merkez ilçelerindeki ortaokullarda okul ve ailenin işbirliği ve sorunları. (Yayımlanmamış doktora tezi). Ankara Ünversitesi, Ankara.

Çakır, E. (2017). Ortaokullarda Aile Katılımına Yönelik Okul Müdürlerinin Görüşleri. (Yayımlanmamış yüksek lisans tezi). Necmettin Erbakan Üniversitesi, Eğitim Bilimleri Enstitüsü, Konya.

Çalışkan, N., Ayık, A. (2015). Okul aile birliği ve velilerle iletişim. Ahi Evran Üniversitesi Sosyal Bilimler Dergisi, 1(2), 69-82.

Çelenk, S. (2003). Okul başarısının ön koşulu: okul aile dayanışması, İlköğretim Online Edergi, 2(2), 28-34. http://ilkogretim-online.org.tr/index.php/io/article/view/2046/1882 adresinden alınmıştır.

Ceylan, M., Akar, B. (2010). Ortaöğretimde okul aile birliği işbirliği ile ilgili öğretmen ve veli görüşlerinin incelenmesi (Karacasu Lisesi Örneği). Çankırı Karatekin Üniversitesi Sosyal Bilimler Enstitüsü Dergisi, 2(2010), 43-64.

Çınkır, Ş., Nayır, F. (2017). Okul aile işbirliğine ilişkin veli görüşlerinin incelenmesi. Hacettepe Üniversitesi Ĕgitim Fakültesi Dergisi, 32(1), 245-264.

Council of Europe (2005). Education for democratic citizenship, 2001-2004, Strasbourg, 22.12.2004, EC. https://rm.coe.int/16803034e5 adresinden alınmıştır.

Dicle, A. (1980). Endüstriyel demokrasi ve yönetime katılma, Ankara: ODTÜ Yayınları, 
Durmuş, E. (2016). Ortaöğretim Kurumlarında Öğretmenlerin Aile Katılımıyla İlgili Görüşlerinin İncelenmesi (İstanbul Sultanbeyli Örneği). (Yayımlanmamış yüksek lisans tezi). İstanbul Aydın Üniversitesi, Sosyal Bilimler Enstitüsü, İstanbul.

Epstein, J. L. (1995). School/family/community partnerships: caring for the children we share. Phi Delta Kappan, 76(9), 701-712.

Epstein, J. L. (2010). School/Family/Community Partnerships: Caring for the Children We Share. Phi Delta Kappan, 92(3), 81-96. https://doi.org/10.1177/003172171009200326.

Erol, Y. C. \& Turhan, M. (2018). The relationship between parental involvement to education of students and student's engagement to school. International Online Journal of Educational Sciences, 10 (5), 260-281.

Eroğlu, H. T. (2006). Yönetime katılma biçimleri ve yerel yönetimlerde demokratik mekanizmalar. Selçuk Üniversitesi İktisadi ve İdari Bilimler Fakültesi Sosyal ve Ekonomik Araştırmalar Dergisi, 6 (11), 191-206.

Gail L. Zellman \& Jill M. Waterman (1998) Understanding the 1mpact of parent school 1nvolvement on children's educational outcomes. The Journal of Educational Research, 91(6), 370-380, Doi: 10.1080/00220679809597566

Güçlü, N. (2000). Okula dayalı yönetim. Milli Eğitim Dergisi, Güz 2000, Say1 148.http://dhgm. meb.gov.tr/yayimlar/dergiler/Milli_Egitim_Dergisi/148/6.htm adresinden alınmıştır.

Gümüşeli, A.İ. (2004). Aile katılım ve desteğinin okul başarısına etkisi. Özel Okullar Birliği Bülteni, 2(6), 14-17.

Kahramanoğlu, R. ve Şahin, H. (2014). Öğrenmeyi Destekleyici Ev Ortamının Veli Toplantılarında Yer Alma Durumunun İncelenmesi. E. Yalçınkaya (Ed.). Küreselleşme Teknolojik Yenilikler ve Eğitim Araştırmaları. https://www.researchgate.net/profile/ recep_kahramanoglu/publication/330113281_bolum_2.pdf adresinden alınmıştır.

Karayazı, A. (2007). Çalışanların Yönetime Katılması ve Öneri Sistemleri. (Yayımlanmamış yüksek lisans tezi). Kahramanmaraş Sütçü İmam Üniversitesi, Sosyal Bilimler Enstitüsü, Kahramanmaraş.

Kartal, S. (2008). İlk ve ortaöğretim kurumlarında velilerin okul yönetimine katılımı. Ahi Evran Üniversitesi Kırşehir Eğitim Fakültesi Dergisi, 9(1), 23-30.

Kazak, E. (1998). Okul-Aile İşbirliği ve Sorunları: Adapazarı Örneği. (Yayımlanmamış yüksek lisans tezi). Sakarya Üniversitesi, Sosyal Bilimler Enstitüsü, Sakarya. 
Kolay, Y. (2004). Okul-aile-çevre işbirliğinin eğitim sistemindeki yeri ve önemi. Milli Ĕ̆itim Dergisi, Güz 2004, Sayı 164. http://dhgm.meb.gov.tr/yayimlar/dergiler/Milli_Egitim_ Dergisi/164/kolay.htm adresinden alınmıştır.

Kotaman, H.(2008). Türk ana babaların çocuklarının eğitim öğretimlerine katılım düzeyleri. Uludă̆ Üniversitesi Eğitim Fakültesi Dergisi, 21(1), 135-149.

Kuluçlu, E. (2008). Türk hukuk sisteminde normlar hiyerarşisi ve sayıştay denetimine etkileri. Sayıştay Dergisi, 71(1), 1-20.

Milli Eğitim Bakanlığı (2001). Okul Kütüphaneleri Yönetmeliği. http://mevzuat.meb.gov.tr/ dosyalar/95.pdf adresinden alınmıştır.

Milli Eğitim Bakanlığı (2005). Öğrenci-Veli-Okul Sözleşmesi Konulu 2005/92 Sayılı Milli Eğitim Bakanlığı Genelgesi. http://mevzuat.meb.gov.tr/dosyalar/1971.pdf adresinden alınmıştır.

Milli Eğitim Bakanlığı (2009). Milli Eğitim Bakanlığına Bağlı Eğitim Kurumlarında, Tanıtım, Mezunları İzleme, İstihdam, Mesleki Rehberlik ve Danışma Hizmetleri Yönergesi. http:// mevzuat.meb.gov.tr/dosyalar/825.pdf adresinden alınmıştır.

Milli Eğitim Bakanlığı (2010). 18. Milli Eğitim Şurası Kararları. http://ttkb.meb.gov.tr/ meb_iys_dosyalar/2017_09/29170222_18_sura.pdf adresinden alınmıştır.

Milli Eğitim Bakanlığı (2012a). Milli Eğitim Bakanlığg Okul Aile Birliği Yönetmeliği. http://www.mevzuat.gov.tr/Metin.Aspx?MevzuatKod=7.5.15878\&MevzuatIliski=0\&so urceXmlSearch=Milli\%20E\%C4\%9Fitim\%20Bakanl\%C4\%B1\%C4\%9F\%C4\%B1\%20 Okul-Aile adresinden alınmıştır.

Milli Eğitim Bakanlığı (2012b). Milli Eğitim Bakanlığına Bağlı Okul Öğrencilerinin Kılık ve Kıyafetlerine Dair Yönetmelik. http://mevzuat.meb.gov.tr/dosyalar/1617.pdf adresin den alınmıştır.

Milli Eğitim Bakanlığı (2012c). Milli Eğitim Bakanlığı Özel Eğitim Kurumları Yönetmeliği. http://www.mevzuat.gov.tr/Metin.Aspx?MevzuatKod=7.5.16154\&MevzuatIliski=0\&so urceXmlSearch=\%C3\%B6zel\%20e\%C4\%9Fitim\%20kurumlar\%C4\%B1 adresinden alınmıştır.

Milli Eğitim Bakanlığı (2013a). Milli Eğitim Bakanlığı Ortaöğretim Kurumları Yönetmeliği. http://www.mevzuat.gov.tr/Metin.Aspx?MevzuatKod=7.5.18812\&MevzuatIliski=0\&so urceXmlSearch $=$ orta $\% \mathrm{C} 3 \% \mathrm{~B} 6 \% \mathrm{C} 4 \% 9$ Fretim adresinden alınmıştır.

Milli Eğitim Bakanlığı (2013b). Öğrenci Okul Kılık Kıyafetleri Konulu 2013/24 Sayılı Milli Eğitim Bakanlığı Genelgesi. http://mevzuat.meb.gov.tr/dosyalar/1654.pdf adresinden 
alınmıştır.

Milli Eğitim Bakanlığı (2014a). Milli Eğitim Bakanlığı Okul Öncesi Eğitim ve İlköğretim Kurumları Yönetmeliği. http://mevzuat.meb.gov.tr/dosyalar/1703.pdf adresinden alınmıştır.

Milli Eğitim Bakanlığı (2014b). Milli Eğitim Bakanlığı Okul Öncesi Eğitim ve İlköğretim Kurumları Çocuk Kulüpleri Yönergesi, http://mevzuat.meb.gov.tr/dosyalar/1706.pdf adresinden alınmıştır.

Milli Eğitim Bakanlığı (2015). Milli Eğitim Bakanlığı 2015-2019 Stratejik Planı. http://sgb.meb.gov.tr/www/mill-egitim-bakanligi-2015-2019-stratejik-plani-yayinlan mistir /icerik/181 adresinden alınmıştır.

Milli Eğitim Bakanlığı (2016). Milli Eğitim Bakanlığına Bağlı Resmi Okullarda Yatılılık, Bursluluk, Sosyal Yardımlar ve Okul pansiyonları Yönetmeliği. http://mevzuat.meb.gov. tr/dosyalar/1812.pdf adresinden alınmıştır.

Milli Eğitim Bakanlığı (2017a). Öğretmen Strateji Belgesi (2017-2023).http://oygm. meb.gov.tr/meb_iys_dosyalar/2017_07/26174415_Strateji_Belgesi_RG-Ylan-26.07. 20 17.pdf adresinden alınmıştır.

Milli Eğitim Bakanlığı (2017b). Milli Eğitim Bakanlığı Eğitim Kurumları Sosyal Etkinlikler Yönetmeliği. http://www.mevzuat.gov.tr/Metin.Aspx?MevzuatKod=7.5.23639\& Mevzu at Iliski $=0 \&$ sourceXmlSearch=sosyal\%20etkinlikler adresinden alınmıştır.

Milli Eğitim Bakanlığı (2017b). Milli Eğitim Bakanlığı Rehberlik Hizmetleri Yönetmeliği. http://mevzuat.meb.gov.tr/dosyalar/1878.pdf adresinden alınmıştır.

Milli Eğitim Bakanlığı (2018). Milli Eğitim Bakanlığı Özel Eğitim Hizmetleri Yönetmeliği. http://mevzuat.meb.gov.tr/dosyalar/1963.pdf adresinden alınmıştır.

Okul Servis Araçları Yönetmeliği (2017c). http://www.mevzuat.gov.tr/Metin.Aspx? MevzuatKod=7.5.24022\&MevzuatIliski $=0 \&$ sourceXmlSearch $=$ okul\%20servis $\% 20$ ara $\% \mathrm{C} 3 \% \mathrm{~A} 71 \mathrm{ar} \% \mathrm{C} 4 \% \mathrm{~B} 1$ adresinden alınmıştır.

Özeke Kocabaş, E. (2006). Eğitim sürecinde aile katılımı: dünyada ve Türkiye'deki çalışmalar, Türk Psikolojik Danışma Ve Rehberlik Dergisi, 3(26), 143-150.

Özyolcu, T. (2017). Ortaöğretimde Yönetime Katılma ve Çalışan Tutumlarının Değerlendirilmesi. (Yayımlanmamış yüksek lisans tezi). İstanbul Gelişim Üniversitesi, Sağlık Bilimleri Enstitüsü, İstanbul. 
Silver, M. (2004). Trends in School Reform, New Horizons For Learning. http://archive. education.jhu.edu/PD/newhorizons/Transforming\%20Education/Articles/Trends\%20in \%20School\%20Reform/index.html adresinden alınmıştır.

Şad, S. N., Gürbüztürk, O. (2013). İlköğretim birinci kademe öğrenci velilerinin çocuklarının eğitimine katılım düzeyleri, Kuram ve Uygulamada Ĕ̈itim Bilimleri, 13(2), 993-1011.

Şimşek, H., Tanaydın, D. (2002). İlköğretimde veli katılımı: öğretmen-veli-psikolojik danışman üçgeni, Illköğretim Online Dergisi, 1(1), 12-16. http://www.ilkogretimonline.org.tr adresinden alınmıştır.

Şişman, M., Güleş, H., Dönmez, A., (2010). Demokratik bir okul kültürü için yeterlilikler çerçevesi. Uşak Üniversitesi Sosyal Bilimler Dergisi, 3(1), 167-182.

Şişman, M. (2010). Türk eğitim sistemi ve okul yönetimi. Ankara: PegemA Yayıncılık.

Tican Başaran, S., Koç, F. (2001). Ailenin Çocuğun Ĕ̆itimine Katılım Sorunları ve Katılımın Sağlanması İçin Alternatif Bir Model, Ankara: Milli Eğitim Basımevi.

Ünüvar, P. (2010). Aile katılımı çalışmalarına yönelik ebeveyn ve öğretmen görüşlerinin karşılaştırılması. Kastamonu Eğitim Dergisi, 18 (3), 719-730.

Vural, S. (1989). Yayın kurumlarında yönetime katılma ve TRT örneği. Amme İdaresi Dergisi, 22(2), 53-75.

Yakıcı, A. P. (2018). Okul Öncesi Velilerinin Aile Katılımını Yordayan Değişkenlerin İncelenmesi. (Yayımlanmamış yükssek lisans tezi). Uşak Üniversitesi, Sosyal Bilimler Enstitüsü, Uşak.

Yaylacı, A.F. (1999). İlköğretim Okullarında Ailenin Okula Katılımı (Ankara İli Örneği). (Yayımlanmamış yüksek lisans tezi). Ankara Üniversitesi, Sosyal Bilimler Enstitüsü, Ankara.

Yıldırım, M.C., Dönmez, B. (2008). Okul aile işbirliğine ilişkin bir araştırma (İstiklal İlköğretim Okulu Örneği), Elektronik Sosyal Bilimler Dergisi, 7 (23), 98-115.

Yıldırım, A., Şimşek, H. (2005). Sosyal bilimlerde nitel araştırma yöntemleri (5. Baskı), Ankara: Seçkin Yayınları. 


\section{Summary}

Problem Statements The education management science is also affected by the improvements which happened in management science in 20th century, the new school management models have been developed, both in theory and practice. Models such as Democratic school, School-based management, School-centered management have common points like the necessity of making sure that all members of the school community, especially the ones who will be affected by the decision, should be arbiters in a matter of decision about school management by participating in decision mechanisms. Thus, the ones who are affected by the decision will take responsibility by owning the adjudication, and the purposes of the management will actualize easily. 
Parental involvement in school is all types of communication and interaction between the school and the parents (Epstein, 1995). Epstein (2010), examines the participation of the family by categorizing them into 6 category, Type 1-Parenting, Type2-Communication, Type 3- Voluntariness, Type 4- Learning at home, Type 5- Decision Making, Type 6Cooperation with the society. The category of decision making is a participation type that express the participation of the teachers, students and parents and them being at the decision mechanisms.

The practices that intend for parental involvement in school are heeded in all of the world countries (Özeke and Kocabaş, 2006). There is a direct correlation between the parental involvement and the quality of the education that students will receive. The parental involvement in school gives positive results in terms of output (Zellman and Waterman, 1998). More effectiveness of the correlation between family and school is possible by the participation of the family (Arslanargun, 2007). In fact, the caring style of the student is the reflect of the caring style of the parents (Epstein, 2010). The main purpose of the correlation between family and school is to inscrease the success of the student and the school (Kotaman, 2008). According to the results of the studies, the correlation between family and school not only increases the success of the student, but also decreases the behaviour of the undisciplined students (Çalışkan and Ayık, 2015; Kahramanoğlu and Şahin, 2014;).

The three most fundamental components of the education are the teacher, the student and the parents. It is stated in the results of the researches that there is a positive correlation between parental involvement and the succes of the student (Tican, Başaran and Koç, 2001). Parental involvement in school in Turkey happens to the extent permitted by national legislations. According to the hierarchy of norms, constitution, law, satutory decree, statue, regulations, anonymous regulatory actions (general communiques, communiques, circulars etc.) makes up the national legislations in Turkey (Kuluçlu, 2008). The purpose of this study is to identify the provisions about the parent involvement in management, which takes place in current national legislations, by examining systematically. When the national legislations are examined, it has been initiated with the 1982's Constitution which is the supreme document according to the hierarchy of norms and is still in effect as of June 2019, the examination is expanded to the inferiror documents in the form of regulations. 
Purpose of the Study. Turkey in the parents' involvement in management rights are managed in accordance with national legislation in force schools are included in the legislation. In this study, in force in Turkey as of June 2019 with the aim of identifying substances which involve the involvement of parents in the management of national legislation. In this direction;

- What is the status given to the national legislation in force in Turkey with the involvement of parents in studies related to management in Turkey?

- What are the rules governing the right to participate in management of the parents as permitted by national legislation in force with the date of June 2019 in Turkey? The questions will be followed by the hierarchy of norms and the answers will be sought.

Method(s). In the research, document analysis method which is one of the qualitative research methods was used. Document analysis is the analysis of written sources containing information about the cases or cases planned to be investigated (Yıldırım ve Şimşek, 2005). In this research the data which is collected by the method of document examining is reviewed with content analysis.

Documents which include subject of the research is required from Ministry of Education's regulation bank in electronic environment (meb.goc.tr/mevzuat). 1982's Constitution, which takes part in this platform and is still in effect as of June 15 2019, 25 laws, 2 Statutory decree, 5 Presidential decree, 1 President's decision, 15 Council of Ministers' decision, 121 regulations, 80 directive, 7 comminique, 17 Procedure and Basis, 334 content texts of circular are surveyed by searching the words "parent" and "family". The sentences which include the words "parent" or "family" in Regulations text are examined in terms of concept of participation in management. The texts in which parents are given right to participate in managemenet are included in the context of the research.

Findings and Discussions: In this research, in which the national legislation documents in Turkey have been examined according to the hierarchy of the norms, it can be seen that because the supreme documents like the Constitution, Law, Regulations have more general and compact matters, the parental involvement in management is regulated more by ordinance. Parents participate in school management more through commitees and commissions, take responsibilty together with the administrator, teacher and the student in the commitees and commissions. Whereas, board of management of the parent-teacher association is only constituted by parents. When deciding on the members of commitees and commissions, it can be seen that the size of the populace that the member represents is disregarded, thereby the 
modulating acquiescence is ignored. According to Kartal's (2008) categorical classification, it has been seen that among 39 regulation matters that regulate the parental involvement in management, 14 of them take place in commitiee membership, 13 of them in commission membership, 5 of them in reporting opinions and suggestions to the management, 7 of them in helping the management. Participation through the commitees and commissions makes up 27 of the 39 matter of participation to the management which the national legislation includes. It has been seen that the commitiees and commissions are more of a places where the parents have an oppurtunity to participate in management directly and the participation act become concrete. It has been determined that the clauses of regulating parents' right to participate in management is mostly in regulations of middle-school intstitutions with 11 clause, the parentteacher association follows it with 9 clause.

Conclusions and Recommendations: It has been seen that in some parts of the studies, which is made hitherto about parental involvement in management, national regulations have not been issued entirely, in other parts it has been issued only partly, and in other parts the repealed regulations have been included in the studies.

Based on this research; If the subject of the research is related to the legal regulations, it is recommended to review the legislation documents in accordance with the hierarchy of norms. It is recommended to use state-owned web sites, such as the official web sites of the state, such as mevzuat.gov.tr, resmigazete.gov.tr, meb.gov.tr/mevzuat Legislation web sites in document reviews conducted on legislation texts. At the same time, it is recommended that review be made after making sure that changes in legislation have been incorporated into the text. On the other hand, the repealed regulations also require special attention. 